\title{
Good economics, bad economics, and European economics
}

Citation for published version (APA):

Backhaus, J. G. (1996). Good economics, bad economics, and European economics. METEOR, Maastricht University School of Business and Economics. METEOR Research Memorandum No. 007 https://doi.org/10.26481/umamet.1996007

Document status and date:

Published: 01/01/1996

DOI:

10.26481/umamet.1996007

Document Version:

Publisher's PDF, also known as Version of record

\section{Please check the document version of this publication:}

- A submitted manuscript is the version of the article upon submission and before peer-review. There can be important differences between the submitted version and the official published version of record.

People interested in the research are advised to contact the author for the final version of the publication, or visit the DOI to the publisher's website.

- The final author version and the galley proof are versions of the publication after peer review.

- The final published version features the final layout of the paper including the volume, issue and page numbers.

Link to publication

\footnotetext{
General rights rights.

- You may freely distribute the URL identifying the publication in the public portal. please follow below link for the End User Agreement:

www.umlib.nl/taverne-license

Take down policy

If you believe that this document breaches copyright please contact us at:

repository@maastrichtuniversity.nl

providing details and we will investigate your claim.
}

Copyright and moral rights for the publications made accessible in the public portal are retained by the authors and/or other copyright owners and it is a condition of accessing publications that users recognise and abide by the legal requirements associated with these

- Users may download and print one copy of any publication from the public portal for the purpose of private study or research.

- You may not further distribute the material or use it for any profit-making activity or commercial gain

If the publication is distributed under the terms of Article $25 \mathrm{fa}$ of the Dutch Copyright Act, indicated by the "Taverne" license above, 


\title{
Good Economics, Bad Economics, and European Economics
}

\author{
Prof. Dr. Jürgen G. Backhaus \\ Rijksuniversiteit Limburg \\ Postbus 616 \\ 6200 MD Maastricht \\ The Netherlands \\ tel: $+31-43-3883652 / 3636$ \\ fax: $+31-43-3258440$
}

Forthcoming in Kyklos 


\title{
Good Economics, Bad Economics, and European Economics
}

\begin{abstract}
The editors of Kyklos have asked the question: Is there a European economics? This short essay tries to give an answer by first trying to provide a framework for a sensible answer in economics, and then following suit by illustrating how in the context of this framework, the answer can be given.

In so doing, the essay touches on theories of regulation, the ORDO-approach, the sub-discipline of law and economics and the problem of European institutions as they are different from American ones and different from those typically assumed but never explicated in textbook renditions bearing on economic policy.
\end{abstract}

J.E.L. code: B19, A11, D23, D73 


\section{Good Economics, Bad Economics, and European Economics}

Introduction

Most professional economists today will agree that there is good economics and bad economics, but that a distinction between for instance American economics and European economics would be senseless.

This assumption is clearly underlying the practice of teaching economics at universities and colleges and it is an assumption shared by textbook authors and publishers. However, recently, publishers are changing their point of view in this matter, and perhaps the economics profession should take notice. After all, markets are systems in which knowledge is being transmitted and used ${ }^{1}$, and the knowledge used by market participants is also available to the professional economist. To wit: If we observe publishers' behaviour ${ }^{2}$ to reveal a sense that there is a difference between economics as it is being practised in Europe on the one hand and in the US on the other, the professional economist better take notice and use this information for his own understanding of the discipline in which she works.

Indeed empirically, we can observe significant differences between the views held by the American economists on the one hand and the European economists on the other. ${ }^{3}$

$1 \quad$ Friedrich August von Hayek, "The Use of Knowledge in Society", $\underline{\text { American Economic }}$ Review, 35, 1945, pp.

2 See for example Robert J. Barro and Vittorio Grilli, European Macro-Economics. London: McMillan, 1994. The authors give the following reason for their European approach: "Europe has been proceeding towards economic integrations at an accellerating speed. National economies have become more and more internationalized by their membership in organisations like the European Community and the European Free Trade Association. It would be impossible to have a clear picture of the evolution of, say, the French economy without any knowledge of how the German economy works, and vice versa.

Our task, however, is less difficult than it may appear at first. We will show that there are basic economic relationships and empirical regularities that hold true for all of the industrialized economies. Therefore, we will need just one basic macro-economic framework to understand the behaviour of the main economic aggregates in the United Kingdom, Germany, or most of the industrialized countries. This is not to say that all countries are identical. To the contrary, there are substantial differences among them, in particular in their institutional and political structures which, undoubtedly, have an impact on economic activity." (pp. 1-3)

Obviously, the authors are not quite sure of whether there is a specific European macro-economics or not. Next to the book cited, Robert Barro, of course, has his Macro-economics (New York: Wiley, 1993 (4))

3 See Bruno S. Frey and Reiner Eichenberger, "Economics and Economists: A European Perspective". American Economic Review. Papers and Proceedings, 82.2, 1992, pp. 
This essay is about possible differences between European economics and American economics. Although I would not deny that the core of economic theory has to be identical across cultures, nations and centuries, I do insist that national economic conditions are different and that for this reason both theoretical emphasis and to an even larger degree the practical work of economists will be different in reflecting different political realities these economists are confronted with. This view is in search of a paradigm, and in trying to sketch the specifics of the development of political economy on the European continent, I begin by reviewing Roscher's approach to writing the History of Political Economy in Germany. It was Roscher who based his work on the explicit assumption of differences in economics as a reflection of differing national realities.

Part I of this short essay outlines the framework and part II offers four different examples in order to show how the framework could be rendered useful.

This would, however, require a more substantial research effort and, conceivably, might be worthy a specific European initiative.

I.

Political Economy and National Reality: Roscher's Approach

Political economy: can it be different from nation to nation? As I have tried to hint at the outset, the question is difficult for the modern economist to address, since the presumption is that national boundaries do not count in the formation of economics as a science. As a matter of fact, the whole concept of being "scientific" is often suggested to depend on the negation of national differences.

In my search for a methodological anchor for this type of approach, I hit upon Roscher's Geschichte der Nationalökonomik in Deutschland (1874). The concept of writing a history of economics for particular countries suits the purpose. As it turns out, the application to Germany was not important for the method at all. Roscher's theory of separating political economy by areas, however, is extremely important for the purpose of this inquiry. We should be honest as we approach delicate questions like these. I am convinced that a student suggesting in an exam situation that the solution offered in a recent article of the American Economic Review was not relevant for his particular country, stands a high chance of failure. I am equally convinced that this expectation is shared by many economists, such as those participating in the Erasmus Program. Proposing the idea, therefore, that it may be worthwhile to pursue the different economic theories as they were differently construed by economists facing different national realities is worthy a venture, and it is indeed a venture worth the ante (of the unorthodox and difficult research effort).

Among the authorities economists tend to respect today, Schumpeter's History of Economic Analysis and Mark Blaug's Economic Theory in Retrospect stand foremost. More sophisticated students will certainly consult the Handwörterbuch der Staatswissenschaft in its various editions, and the old and the new Palgrave. In any event, if the student is thorough enough, she will encounter the name of Roscher someway mysteriously. E.g., in Ekelund's and Hébert's

216-220 with further references. 
A History of Economic Theory and Method, ${ }^{4}$ Roscher is hailed as a major figure, but it remains completely unknown to the reader wherein the accomplishments may have consisted. Did he launch a theorem? Did he invent a new process for decision taking? Did he launch a program for social reform? The answer is none of all the above. Roscher suggested and that is interesting for the rest of us, a way of writing the history of economics which enables us to answer the question posed in this article. Roscher's History of Political Economy is expressly devoted only to German developments. The title is: Geschichte der Nationalökonomie in Deutschland. The contemporary reader has to ask herself. What kind of theoretical presumptions the author might have hatched. As we look around, there is no lack of misunderstandings of what Roscher had in mind.

Whereas the idea guiding Blaug is obviously that there is in some sense progress in economics, in that our ability to understand the economic processes increases, he at the same time also tries to dissociate economics from the different structures to which economics would have to be applied i.e from those very processes. Roscher's approach on the other hand is completely different. He argues that economic practice which is obviously related to economic institutions and determined by the specific circumstances of time and place, determines economic thinking. Hence, Roscher seems to be as good a candidate as anyone to support a relativist approach to the history of economic thought. The optimal strategy for a particular set of economic policies is relative to the circumstances in which you have to formulate it. As historians of economic thought, we try to document the way in which economists of previous times argued and thought. The task is to critically reconstruct these arguments and thoughts in order to understand the accompanying accomplishments. Roscher's History of Political Economy in Germany is by way of its title and intention only devoted to what went on in Germany and formed the basis for the work of German economists. For this task, the work of economists outside Germany is only relevant to the extent that it influenced German economic policy. Hence, the selection of authors also has to be guided by the extent to which they had an impact in practice.

Blaug's approach is different in almost every respect. In formulating his position, Mark Blaug 5 is as usual circumspect.

"No assumptions about economic behavior are absolutely true and no theoretical conclusions are valid for all times and places, but would anyone seriously deny that in the matter of techniques and analytical constructs there has been progress in economics? Adam Smith, e.g. had a firm grasp of the way in which the market mechanism is capable of coordinating the independent decision of buyers and sellers, but anything as fundamental as the functional relationship of demand and prices escaped him. It never occured to him that it was possible to demonstrate precisely in what sense a decentralized economy produces optimum results and it took a hundred years before Walras, Marshall, Pigou and Pareto worked out the logic of Smith's convictions about the workings of 'the invisible hand'. Thougths such as these produced the absolutist who, looking down from present heights at the errors of the ancients, cannot help but

$4 \quad$ New York: MacGraw Hill, 1990 (3). The authors describe Roscher's work largely as a failure and call his Principles 'a beautiful sunset' (p. 254).

5 Economic Theory in Retrospect. Cambridge: Cambridge University Press, 1985 (4). 
conclude that truth is largely concentrated in the marginal instrument to economic knowledge.

It is very likely that absolutists are created by reading the works of too many relativists. It is difficult nowadays to appreciate the freshness of Canon's icono-clastic approach in his famous book The History of The Theories of Production and Distribution (1893) - a veritable catalogue of the elementary blunders of great economists - to a generation nurtured on the relativist texts of Blanqui, Roscher, Ingram and Cossa" (pp. 3-4).

While Blaug does not completely deny the importance of time and place, the different national realities certainly do not get center stage as he watches the development of the work of economists from his presumably high ground. Yet, he somehow combines the issue of the development of techniques and analytical constructs with the, in principle, separate issue of progress in economics. An alternative approach would involve the definition of progress in economics as the degree of success with which economists design and implement policies that sought to meet the requirements of the different national realities. The development of techniques and analytical constructs would have to be judged in terms of their marginal impact in achieving the practical progress in economic policy. In any event, the relativist position attributed to Roscher and others does not involve the denial of progress in economics. In fact, Roscher himself wrote his History of Political Economy both as a history of progress and as a history of economics in the context of different national realities.

Roscher's History of Political Economy is based on the very assumption that political economy is bound up in the context of national realities. His History of Political Economy explicitly deals with Germany, and Germany only. ${ }^{3}$ This immediately raises the question of how Roscher justifies his relativist approach. Can the history of a social science such as economics be written for a single country? Is there according to Roscher a German political economy which is different from political economy in other countries? Authors such as Blaug would of course deny even the possibility of raising the question. Blaug writes his Economic Theory in Retrospect as a series of blunders and errors on the way to a more refined and unified science of economics:

"'The history of the body of received doctrine goes back to at least as far as Adam Smith. I am not concerned, however, with historical antecedents for their own sake. My purpose is to teach contemporary economic theory. But contemporary theory wears the scars of yesterday's problem now resolved, yesterday's blunders now corrected, and cannot be fully understood except as a legacy handed down from the past. It is for this reason that I have adopted a historical presentation". ${ }^{4}$

Here, Blaug clearly states what he considers the absolutist position. On the other hand,

3 Wilhelm Roscher, Geschichte der Nationalökonomik in Deutschland.

Auf Veranlassung und mit Unterstützung seiner Majestät des Königs von Bayern, Maximilian II herausgegeben durch die historische Commission bei der königlichen Akademie der Wissenschaften. München: Oldenbourg, 1874.

Mark Blaug, 1985, VII. 
Roscher's purpose in writing the History of Political Economy is not to inform us just about economic theory. It is a book about economic theory, but Roscher also covers economic insights which cannot be called the results of theoretical research.

For this, he gives an explicit reason: ${ }^{5}$

"Germans, as well as others have arrived at an economic theory only fairly late. Already in our youth we can register situations and live through developments, we can do great deeds and create wonderful pieces of art. But in order to systematically reflect upon something, we need the maturity of our intellect which peoples just as well as individuals can reach only in later stages of their life. As a rule, the systems of economics are younger than e.g. those of government and diplomacy; similarly, in the natural sciences the movement of the stars can be explained much earlier than such simple processes as cooking or fertilizing."

Economics according to Roscher includes the opinions and principles (p. V) of practical political economists (p. V) i.e. the principal concepts and ideas which form the basis of economic policy. If that is the definition of economics, a history of economics has to fulfill a completely different purpose than in the case of Mark Blaug who wants to teach economic theory by relying on the historical method. Instead of solving the problems and puzzles of contemporary economic theory, Roscher writes the History of Political Economy in order to solve the riddles of history, the riddles of economic history in particular. Roscher emphasizes this difference in explicitly disagreeing with Jean Baptiste Say (1767-1832) who had taken a position similar to Blaug's. ${ }^{6}$ This is how Roscher deals with Say's opinions, ${ }^{7}$ he first reports them faithfully!

"As is well known, J.B. Say thought very lowly of the usefulness of the history of

Roscher, 1874, p. 4.

"Zu einer volkswirtschaftlichen Theorie ist es bei Deutschen wie Anderen erst verhältnismässig spät gekommen. Schon die Jugend vermag nicht bloss Zustände und Entwicklungen zu erleben, sondern auch grosse Thaten zu verrichten, schöne Kunstwerke zu erschaffen. Um aber systematisch über alles diess zu reflectiren, wird eine Reife des Geistes erfordert, welche sich bei Völkern wie bei Individuen erst im spätern Leben ausbildet. Und zwar sind regelmässig die Systeme der Volkswirtschaft noch jünger, als die der s.g. höhern Politik: gerade so, wie die Naturforschung weit früher die Bewegung der Himmelskörper, als die einfachen Vorgänge des Kochens, Düngens etc. ergründet hat".

6 The positions are similar, but in no way identical. While Say flatly denies the usefulness of the history of economic thought, Blaug, of course, thinks otherwise.

$7 \quad$ Roscher, 1874, p. V.

"J.B. Say hatte bekanntlich von dem Nutzen desjenigen, was er unter Geschichte der politischen Ökonomie verstand, nur eine sehr geringe Meinung. 'Was würde es uns frommen, alberne Ansichten und mit Recht verrufene Lehren zusammenzutragen? Ihre Wiederausgrabung wäre ebenso unnütz, als widerlich. Darum wird die Geschichte einer Wissenschaft immer kürzer, je mehr die Wissenschaft sich ausbildet. Denn nach dem, was andere Leute gemeint haben, forscht man nur aus eigenem Mangel an festen und klaren Begriffen.'" 
political economy. What would be the use, he asked rhetorically, of collecting the silly views of people whose reputation is rightfully bad? This excavation would be as useless as it would be repulsive. The history of a science becomes the shorter the further the science has developed. You look for the opinions of others only for lack of your own clear and solid notions".

The author of the 1.093 pages of The History of Political Economy in Germany obviously did not share the opinion that the history of economics gets shorter with its further refinement. He argued against Say: ${ }^{8}$

"Such views require no explicit rejection. The only relevant distinction is between old and out of date. In the arts and sciences only the insignificant can become out of date. But the insignificant has probably never been fresh and new. What is really relevant and important during a particular period of time can never become out of date! It is a general rule that only those people are truly interested in the future who are at the same time interested in the past. The leading intellectuals are similar to high mountains which receive the evening sun of the waning day the latest and are the first to reflect the morning sun of the following day."

To summarize, the history of political economy according to Roscher holds the key for understanding the history of a particular country. It is for this reason that the history of political economy cannot be universal, but has to be relative and special in many respects.

Although Roscher has written The History of Political Economy in Germany, he nevertheless insists on the concept of a universal theory of political economy. He compares the development of political economy in Germany with the development in other countries, and in particular in England. It is interesting for understanding his approach to look at one of these comparisons as we find them frequently in the text: ${ }^{9}$

Roscher, 1874, p. IV-V.

"Solche Ansichten bedürfen heutzutage keiner ausdrücklichen Widerlegung. Man muss nur zwischen alt und veraltet zu unterscheiden wissen. In der Kunst, wie in der Wissenschaft veraltet bloss das Unbedeutende: man könnte von diesem aber zweifeln, ob es jemals wahrhaft jung gewesen. Das für irgend eine Zeit wahrhaft bedeutende veraltet niemals! So findet man ja auch regelmässig, dass nur diejenigen Menschen wirkliches Interesse für die Zukunft besitzen, die sich zugleich für die Vergangenheit interessieren. Und die geistig hoch stehenden Menschen gleichen den hohen Bergen, die noch am spätesten die Abendsonne des vergangenen Tages und schon am frühesten die Morgensonne des folgenden widerspiegeln". (S. IV-V)

Roscher, 1874, pp. 236-237.

"Vergleicht man diese deutsche Literatur im Ganzen mit der gleichzeitigen der fremden Völker, so steht sie der englischen ohne Zweifel nach. Diese hat gerade im 17.

Jahrhundert, auf der gesunden Unterlage der vortrefflichen Kolonisationsschriftsteller, nach der von Bacon gelehrten Methode, mit Hilfe des klaren Scharfsinnes von Hobbes, zuletzt in dem grossen Triumvirate der Petty, Locke und North eine Höhe gewonnen, die zwar nachher fast zwei Menschenalter hindurch in ihrer Weiterentwicklung ge- 
"As we compare the German literature in its entirety with the contemporary literature of the foreign nations, we can have no doubt that it ranks behind the British. The British literature during the 17th century reached a climax. This development was possible due to the solid foundations of the excellent authors who wrote on the colonies, it was possible due to the methods taught by Bacon, and due to the sharp intellect of Hobbes, finally due to the great triumvirate of Petty, Locke and North. Yet, for two generations, this very achievement stood in the way of further development. This period of stagnation may be seen as the gestation period for what can be called the goldon age of British political economy from Hume and Tucker to Malthus und Ricardo. A similar classical predominance as the Italians enjoyed during the 15th and 16th century with their great painters can be claimed by the British in the area of political economy. This is true not only for the 18th, but similarly already for the 17th century, when the development of political economy beautifully paralleled the development of the natural sciences, which had been started by Bacon, continued in the Philosophical Transactions of the London Royal Society and found its climax in Newton's Principia philosophiae naturalis mathematica (1687). On the other hand, we cannot claim a similar predominance for the Italians. Still, during the 16th century they fully did justice to their reputation as the earliest and most developed of the new nations, and

hemmt wurde, jedoch als die unmittelbare Vorstufe der goldenen Zeit britischer Nationalökonomik von Hume und Tucker bis auf Malthus und Ricardo gelten muss. Ein ähnlich klassischer Vorrang, wie ihn die Italiener im 15. und 16. Jahrhundert auf dem Gebiete der Malerei besessen haben, gebührt den Engländern auf dem Gebiete der Nationalökonomik, und zwar nicht bloss im 18., sondern verhältnismässig ebenso sehr schon im 17. Jahrhundert, wo sich ihre Nationalökonomik in schönster Parallele zu jener Naturwissenschaft entwickelt hat, welche durch Bacon eröffnet, in den philosophical Transactions der Londoner königlichen Gesellschaft fortgesetzt worden ist, um in Newton's Principia philosophiae naturalis mathematica (1687) ihren Gipfel zu erreichen. - Von den Italienern dagegen lässt sich eine solche Ueberlegenheit keineswegs behaupten. Noch während des 16. Jahrhunderts hatten Sie den Ruhm, das frühest und höchst entwickelte aller neueren Völker zu sein, auch auf dem Felde der volkswirtschaftlichen Theorie ebenso gut, wie auf dem der volkswirtschaftlichen Praxis, bethätigt. Allmählich aber musste der bleierne Druck, welchen die spanische Herrschaft auf sie legte, und die Erstarrung, worin auch die selbständiger gebliebenen Theile der Nation fielen, wie der Kirchenstaat und Venedig, selbst die Wissenschaft lähmen; und erst im 18. Jahrhundert gelang es französischen und deutschen Einflüssen, zumal über Neapel und Mailand, einen neuen Aufschwung herbeizuführen. Von Spanien gilt dasselbe in noch höherm Grade. Was endlich die französische Nationalökonomik betrifft, so hatte sie im 17. Jahrhundert vor der deutschen zwei grosse Vortheile. Einmal, dass sie sich, zumal durch Colbert, ebenso vielseitig wie grossartig concentrirt, im praktischen Leben bethätigen konnte, während die deutschen Theoretiker wegen der politischen Gestalt ihres Landes nur zu sehr entweder Predigern in der Wüste, oder Luftschlossbaumeistern glichen. Sodann auch, dass sie in einer Sprache schrieb, welche ihren, für alle Zukunft gültigen, klassischen Höhepunkt erreicht hatte, während unsere Sprache gerade zu jener Zeit eine Form trug, welche die besten Schriftsteller zu raschem Veralten und Vergessenwerden fast nothwendig verurtheilte. Abgesehen hiervon, wird man eine grosse Ueberlegenheit der damaligen französischen Volkwirthschaftslehre nicht behaupten dürfen." (S. 236-237) 
they lived up to this reputation in the area of political economic theory as they did in the area of political economic practice. Yet with the passage of time, the leaden pressure of the Spanish rule, and the paralysis into which those parts of the nation likewise slipped which had managed to retain independence such as the Papal State and Venice had to lead to a paralysis of science as well. Not before the 18th century, French and German influences by way of Naples and Milan succeeded in bringing about a new upswing. For Spain the same can be said to an even larger degree. As far as finally French political economy is concerned, we can say that during the 17th century it enjoyed essentially two advantages over the German one. On the one hand, French political economy could be applied in practice, and this was in particular possible due to the manyfold and magnificant efforts of Colbert. At the same time, the German theoreticians, due to the political structure of their nations, could either be likened to prophets in the desert or architects of dream castles. The second advantage of the French political economists was their language. They could write in a language which had already achieved its classical form which it should keep in the future, whereas the German language of this time still had a form which condemned even the best of authors to being quickly out of date and soon forgotten. Apart from these two advantages, it is impossible to claim that French political economy was superior to its German counterpart."

Roscher is capable to judge the performance in political economy not just of particular authors, or of their particular contributions, but in an overall way of entire nations and to do so in a comparative fashion. He emphasizes objective determinants of the maturity of an economic doctrine, and he does so by using a functional relationship. In the quote given above, the state of a doctrine and political economy is functionally dependent on three arguments:

1. The method

2. The political practice

3. The language

As far as the method is concerned, it is clearly characterized with the names of Bacon, Hobbes and Ricardo if we do not forget the additional aspects which Roscher associates with Colbert's name.

For Roscher, the practice of economics, i.e. economic policy is where the theory has to be tested. Only both economic doctrine and the implementation into forms of economic policies form what Roscher calls political economy. Obviously, the options of economic policy are determined by the discretionary leeway of the practical political economists. This leeway or scope for economic policy in turn is dependent on two aspects: on the one hand, the state of economic development of a nation circumscribes the economic policy options. On the other hand, the scope of economic policy is shaped by the political structure of the nation. In Roscher's words, this political structure can either rest heavy as lead on the cultural, economic and political life of a nation, or it can stimulate a wonderful concentration on the essential policies and initiatives, and thereby offer the opportunity to implement economic theory into practical economic policies. According to Roscher, this magesterial performance was possible in France at the time of Colbert, but also in England's colonial empire.

The fortunate climax of French political economy at the time of Colbert is thirdly, according to Roscher, possible because of the level of perfection that the French language had already 
achieved in Colbert's time. The language as a determinant of the state of political economy must be seen as completely Roscher's own contribution to writing the history of economic thought. The language, however, is not necessarily tied to the nation. Obviously, political economists are to a certain extent free to choose the language in which they want to express their theories. Today, most economists opt for mathematics as the language of their choice. The authors Roscher covered often chose either a French or Latin. But, as Roscher insists, theory cannot be separate from practice, and the practical applications will require certain forms of expressing the theories. If you want your theoretical work to be useful, you have to express it in such a way that it can be understood and mastered by the practical economists. If the language of the practicioners lacks precision, breath and depths, this will also limit the extent to which complex theoretical work can be expressed.

II.

Wilhelm Roscher's History of Political Economy in Germany, of course, stops more than 120 years ago. His approach, however, leaves us to various examples, which illustrate the difference between European and trans-atlantic economics as it is due partly to the method of analysis, partly to the political practice, partly to the differences in language and partly to the combination of these. For the sake of brevity, I have chosen four different examples, which I hope can illustrate not only the extent of the differences but also the reasons for their existence.

\section{A. Theories of Regulation}

In the United States, public utilities tend to be privately owned, yet to be subjected to specific governmental supervisory bodies, which have to approve rates, often product quantities and types and the like. This governmental supervisory activity is called "regulation" and has given ries to a substantial body of theory (J.E.L. code: L 5) and various specialized journals such as the Rand Journal.

On the other hand, in Europe there tends to be a substantial public enterprise sector, and the governmental activity referred to as regulation plays a rather more modest role. Sometimes, regulatory activities increase as a consequence of privatization, however. Consequently, where the European contribution to theories of regulation is relatively weak, there exists a strong body of theory and practical work, devoted to public enterprise economics (J.E.L. code: L 3). Although there is not a single journal in the area of regulatory economics on the European continent, there are several devoted exclusively to public enterprise economics, such as the Annals of Public and Co-operative Economics now in its 66th volume, or the Zeitschrift für öffentliche und gemeinnützige Unternehmen now at volume 18.

Similarly, regulation is a standard course in the US economics curriculum, whereas public enterprise economics tends to be offered at European universities (covering such topics as public pricing, public investment behaviour, public performance). Even despite extensive privatization operations, this difference is unlikely to go away, as the public enterprice sector tends to increase even in the face of large privatization operations. The difference between the US American economy on the one hand and the European economies on the other is both a difference in the structure or better "style" ${ }^{10}$ of the respective economic systems and, only

10 The concept of "style" of economic conduct is a key notion we owe to the historical school. It was used by Schmoller, Sombart, Spiethoff and Schumpeter, who took style as a term of economic sociology. In order to understand and correctly interpret econo- 
partly as a consequence, a difference in economic policy instruments and outlook.

\section{B. ORDO}

Tightly tied to the German language area is a body of economic theory emphasizing the economic and legal order which provides the framework in which economic activity can take place. The traditional theory was founded by the German economist Walter Eucken (18911950) and the lawyer Franz Böhm (1895-1977) who for a while both taught at the University of Freiburg. This body of theory is discussed in numerous publications including a journal by the name of ORDO (now in its 46th volume)(Latin for order) for which there is no English term. Although Eucken's main work Die Grundlagen der Nationalökonomie 1940 (Jena: Gustav Fischer) has been translated by Terrence W. Hutchison as "The Foundations of Economics. History and Theory in the Analysis of Economic Reality" and published in 1950 (London: Hodge), this body of work has almost had no reception or response by Anglo-Saxon economics. ${ }^{11}$ Needless to say, there is no entry for Ordo theory in the J.E.L. classification index.

The reason for the singularity of this body of theory is partly historical, but also a result of the specific method employed. Economists working in this tradition draw heavily on both law and economics, a possibility offered to German economists at a time when economics was still taught within the context of the law schools. This is, of course, no longer the case, and therefore the economics graduate of a German university typically has no or a very small background in law. Next to the method, the specific historical circumstances of Germany during the 30s and 40s of this century were interpreted as a challenge by, and to those economists working in the ORDO tradition. The denaturation of the political system and consequently the instrumentalization of the economic system to political ends was seen as a systematic flaw due to the breakdown of the rule of private law (Privatrechtgesellschaft) which garantees not only free markets but also free political choice. Only some of these themes have later been taken up by public choice economists, and ORDO is still largely a German monopoly in economic theory.

\section{Law and Economics}

The subdiscipline of law and economics occupies an entire letter in the J.E.L. classification

mic phenomena, one may want to look at the leading ideas and convictions (spirit) to which people subscribe and which will guide their actions; secondly at the techniques at their disposal; and thirdly at the organizational forms in which means and ends are combined or alternatively, in which spirit and technique find their institutional realization.

Spiethoff actually gives five categories, i.e. the economic spirit, the natural and technical resources, the constitution of society, the constitution of the economy, and the economic process. For details see Spiethoff (1932) or Schefold (1981, p. 113). The term "style" should be taken as a technical term and not be read as the opposite of "substance". Differences in economic style are a matter of substance indeed.

11 But see a special issue of the Journal of Economic Studies (Vol. 21, nr. 4, 1994 edited by Gerrit Meijer with further references). 
system, but it is an extremely strange classification approach.

In principle, law and economics could be organized according to two principles. Either it could be organized in terms of the economic theories used so as to explain legal institutions, procedures, decisions and the like, or it could be organized in terms of the legal subject areas on which different economic theories were brought to bear.

The J.E.L. classification system largely follows the second approach, and here clearly opts for the American legal system instead of the European one. The basic difference is that the American system is based on common law, with public law being mainly regulatory law and somewhat of an intrusive factor requiring a different approach. Next to this stands penal law. Under the European system, there is the codified civil law, next to it public law with constitutional law and administrative law as its subdisciplines, further commercial and company law, penal law, international law and the like.

The J.E.L. classification system develops the area of law and economics as if it were an area of research totally devoted to American legal practice. It defines the basic areas of law as property law and contract law, tort law and "product liability law" and criminal law as well as "other", which makes sense only in a common law area.

Property, contract and tort all are part of the civil code, product liability is an exemption, and criminal law is subject to a different code.

The legal doctrines and methods governing civil law and penal law (criminal law) are basically different.

This is mentioned here only because the same can be said about the other subheadings, the implication being that law and economics in the Anglo-American tradition is seen as a reflection of the peculiar legal system very much as Roscher saw economic doctrine as being largely dependent on economically relevant institutions.

In Europe, on the other hand, law and economics has a very long tradition, but there was never any particular need to single it out as a seperate discipline, requiring an entire letter in the categorization system, because for a long time, approximately until the second World War, it was self-evidently understood that a good economist would also master the basic areas and problems of law.

Hence, law and economics up until that time was a basic ingredient of good economic analysis, which is why it looked so institutionally rich (or else analytically poor).

Interestingly enough, this difference between European law and economics and American law and economics also is reflected in the behaviour of law and economics scholars. My own empirical research has shown that European law and economics scholars tend to publish their research primarily in non-economic journals, and very few of them, only a handful, actually publish regularly in the international law and economics journals. On the other hand, they tend to launch their work in high circulation legal publications. On the other side of the Atlantic, the picture is reversed. There, the legal publications are typically student run law journals, and authors in law and economics try to publish their work in economics department based law and economics journals, at least in such journals that are run by professional economists. This difference in publishing behaviour reveals a very substantial difference in the implicit understanding of law and economics practitioners of the field in Europe on the one hand and in the trans-Atlantic scholarly community on the other.

D. The European Institutions.

The European Community for some time has tried to enter into science (including economics) 
as a policy area, launching a mulitude of programs which leave their mark on the way scholarly work is done.

The Treaty of Maastricht actually establishes this policy area as a genuine pursuit of the European Union. Since with only minor exceptions the university systems of all Member States of the European Union are public monopolies, and since these systems are generally considered not to be covered by article 85 of the Treaty of Rome but rather considered as the statutary exemptions (as opposed to the discretionary exemptions), establishing science policy as a European Union concern allows for a substantial and rather protective turf.

No similar arrangement exists on the other side of the Atlantic.

The impact of this institutional policy choice on the practice of scholarly pursuit can only be underestimated. The large scale tourism of students and professors under the Erasmus program freely roaming between European universities like medieval migrant scholars has become a homely part of leading European research universities.

Less benign are other aspects. The free movement of labor includes the free movement of professionally trained people, i.e. the output of the Member State university monopolies. In order to harmonize this free movement, the harmonization of degrees is necessary, which in turn requires a relative assessment and conversion scale for the different degrees between the various Member States. This in turn requires the assessment of the performance of the various degree granting departments and institutions, and that in turn requires a definition of a common scale. The definition of the common scale can only be done in terms of disciplinary professional standards, which is where the notion of quality assessment of publications and research enters.

At this point, the exasperated evaluator grasps the last straw which is given to him in the form of the J.E.L. classification system already mentioned and a list of journals ranked by their international priority.

Combine the classification system with the journal ranking, and you arrive at indicators which cannot only help in the process of converting degrees but also help in driving budgetary flows. At this point, the system starts to drive research investments, as investments not adequately classified in the document on which the keys are based are futile from the point of view of the prudent university administrator. Since the entire system is organized as a set of government monopolies in co-operation, no credible option excists for the affected researchers: voice options are limited and loyalty is being taxed. ${ }^{12}$

This, in turn, is yet another scenario explaining why European economics will also in the long run be different from American economics, primarily due to different institutional practices. It can only be hoped that competition between the two systems will allow the end consumer to chose good economics and reject bad economics, whether it is European or not. 


\section{References}

Barro, Robert J. and Vittorio Grilli (1994): European Macro-Economics. London: McMillan, $1-3$.

Barro, Robert (1993 ): Macro-economics. New York: Wiley, (4).

Blaug, Mark (1985): Economic Theory in Retrospect. Cambridge: Cambridge University Press, (4).

Ekelund, Robert B. and Robert F. Hébert (1990): A History of Economic Theory and Method. New York: MacGraw Hill, (3).

Eucken, Walter (1940): Die Grundlagen der Nationalökonomie. Jena: Gustav Fischer. Translated by Hutchison, Terrence W. (1950): The Foundations of Economics. History and Theory in the Analysis of Economic Reality. London: Hodge.

Frey, Bruno S. and Reiner Eichenberger (1992): Economics and Economists: A European Perspective. American Economic Review. Papers and Proceedings, 82.2, 216-220 .

von Hayek, Friedrich, August (1945): The Use of Knowledge in Society, American Economic Review, 35.

Hirschman, Albert O. (1970): Exit, Voice and Loyalty. Cambridge: Harvard University Press.

Meijer, Gerrit (ed.) (1994): The Institutional Basis of Market Economies: Walter Eucken's Contribution to Economics, Journal of Economic Studies, Vol. 21, nr. 4.

Newton, Sir Isaac (1687): Principia philosophiae naturalis mathematica, 236-237.

Roscher, Wilhelm (1874): Geschichte der Nationalökonomik in Deutschland. München: Oldenbourg.

Schefold, Bertram (1981): Die beiden Wege. Meier-Abich/Schefold, 133-162.

Spiethoff, Arthur (1933): Die Allgemeine Volkswirtschaftslehre als Geschichtliche Theorie: Die Wirtschaftsstile. Spiethoff, Arthur (ed.): Festgabe für Werner Sombart zur Siebenzigsten Wiederkehr Seines Geburtstages. Neunzehnter Jänner 19933. München: Duncker \& Humblot, 51-84 